\title{
Delays in Services and Customer Service Evaluation: A Study of Family Dining Restaurants of Pakistan
}

\author{
Maqsood Ahmad", Hina Naseer \\ Department of Management Sciences, Iqra University Islamabad, Islamabad, Pakistan \\ Email address: \\ maqsood366@yahoo.com (M. Ahmad),hniyaleo@gmail.com (H. Naseer) \\ ${ }^{*}$ Corresponding author
}

To cite this article:

Maqsood Ahmad, Hina Naseer. Delays in Services and Customer Service Evaluation: A Study of Family Dining Restaurants of Pakistan. Journal of Investment and Management. Vol. 7, No. 4, 2018, pp. 108-116. doi: 10.11648/j.jim.20180704.11

Received: June 26, 2018; Accepted: July 27, 2018; Published: August 17, 2018

\begin{abstract}
Wait management is very important subject in service sectors because people are moving towards services due to globalization and now it has become common phenomena. Dining at restaurants has become a trend in today's world due to increasing demand of family's as well as time constraints. In developed countries, there is much focus on service sectors and it is producing half revenues ( $\$ 1.258$ trillion) of countries like USA, UK, and Japan. However, in developing countries, a service sector has not yet generated much revenue because it seems difficult for developing countries to handle it due to different demands and niche of customers. In current study, 400 questionnaires were distributed to respondents and 300 were received back. Data was analyzed using SPSS version 17 and results revealed that if good environment is provided at waiting area of restaurant lobbies, then waiting customer behavior can be managed and consequently customer satisfaction. Our results also revealed that physical environment has a positive relationship with customer satisfaction and when this relationship is checked through mediating variable (customer behavior during wait), it also shows positive relationship. On the contrary, social environment has a negative relationship with customer satisfaction and when this relationship is checked through mediating variable (customer behavior during wait), it also shows negative relationship.
\end{abstract}

Keywords: Physical Environment, Social Environment, Waits Management, Customer Behavior, Customer Satisfaction

\section{Introduction}

Waiting for service is a prevailing element in many service settings. Customer has to wait for minutes, days, and months for that service before or after purchasing that service. Customers wait for service because either they gather or they reached too early for that appointment. In reality, people hate too much of waiting that they preferred to hire a person for this activity [12]. Therefore, speed of service has gained very important service characteristics in today's world. We can wait for 30 minutes at bar with friends but if we have to wait for 10 minutes at any pharmacy shop where our basic need is being fulfilled, we used to balk and complain. People are ready to waste their 50 percent of time in amusement park [20] but if this wait, happened at coffee shop they complain. The wait for service is often considered as periphery to core service, whereas, actually it is making the first contact with the series of experience that any customer has with firm [8].
Time is very much precious to consumer and its importance has gained more acceptances due to increasing demands of family members day by day. It has mainly two costs, one is economic, and other is psychological. Economic cost of time has its importance as people have already planned and organized their time for earning activities, however in psychological cost, people mindset used to be disturbed from long waiting. For instance, if a customer has to wait for service then he can be irritated, annoyed, frustrated, and recalls service with bad experience. However, psychological cost has more adverse effect on human behavior than economical cost because irritated and frustrated man is more dangerous for an organization. Customers normally overestimate waiting time from the actual time. It is generally assumed that "the average customer's perception of waiting time is different from reality" with the majority of customers, think that from actual waiting time, they have waited longer. They also found that customer's overestimation time is 40 percent. Similarly, 
overestimation of waiting time is also being supported by other studies as well. Researchers carried out a study in retail industry and proved that in shopping perspective, overestimation of waiting time by customers is by 36 percent [16]. Similarly, in banking sector, overestimation of waiting time is 25 percent [18]. Additionally, it is stated that overestimation rate in their study is 77 percent and the difference between actual and perceived wait is called estimation error and the gap between the actual waiting time and perceived waiting time had been remained an area of investigation for researchers.

Delays in services can be managed by two ways, through operation management or perception management [18]. In operation management, management have to increase the number of employees as per the customer traffic however, this process is viable but more costly. On the other hand, if an organization would able to manage the waiting experience through perception managements then it is less costly and customer would not feel much wait although they are waiting. In addition, operation management is actual waiting time management and perception management is perceived waiting time management [37].

\section{Literature Review}

The researchers like first time gave the idea of atmosphere in marketing and suggested that it could be used as a marketing instrument [21]. However, model of stimulusorganism-response (SOR) on environmental psychology is being applied in this research framework [28]. The physical and social environment acts as stimuli (S) on customer behavior $(\mathrm{O})$ and ultimately behavioral intention in the form of customer satisfaction (R).In addition, it was also found that atmosphere could be attention diverter from wait, as it takes away customer from wait and customer will feel entertainment [13]. Moreover, it has gained much momentum latter on by the addition of many researches. Mainly our research framework is based on three key areas: marketing [6], environmental psychology [28] and perception management [37].

Environment is used as mnemonic in making good or bad experience of customers. In environmental psychology, it is normally said that people react differently to physical environment, for example with approach behavior and avoidance behavior. Approach behavior is an optimistic behavior and in this, individual engage, explore information's, and associate himself with that environment. He has desired to stay there and attached himself with that particular environment because he is getting some information. On the other hand, in avoidance behavior, individual likely to have pessimistic approach and remained passive. He does not stay there and even explores that environment [28].

+Environmental psychology literature suggests that diverse sort of behavior could be due to diverse waiting area characteristics: that if individuals, for examples explore the servicescapes in which services are offered then he will stay there with good interaction. Conversely, if he does not provide such attractive environment then he will remain passive [29]. Occupied time may feel less long than unoccupied time because individual's attentions are being distracted from long waits [23]. Once a good interaction between environment and customer is being provided then it can cause distraction from waits as the waiting problem remained pregnant until the individuals are passive.

Service environment cues lead to individual supposition and expectation about restaurants foods, services providing, prices, and visiting costs that in turn affect restaurant patronage intentions [13]. For instance, if the physical and social settings of environment are properly arranged as per the taste and preference of customers, then there is possibility that customer can compromise poor food quality on better services else not. Service environment can also affect positively on customers' way of spending money during stay as once customer explore environment and he will likely to pass his time more there and customer spending pattern will automatically increase [6].It is also observed that physical and social environment in waiting area not only provides good interaction between customer and service but by having so, attention from wait can be distracted and it also have positive effect on customer satisfaction and repeat visit.

\subsection{Physical Environment}

Researchers defined environmental psychology theory by Stimuli-Organism-Response model (SOR). He said that there should be some stimuli (S), affecting on organism $(\mathrm{O})$, and inducing emotional reaction $(\mathrm{R})$ on individuals [28]. The physical environment is one of the stimuli that act as point of pivotal and it is directly affecting on customer behavior during wait for service. However, the behavior of customers is very complicated subject that is formed by mixing their attitude and other related aspects. In service sectors, where waiting is a prevailing problem, customers always overestimate waiting time and this is bad thing for managers. Managers are making efforts in real time for enhancing customer satisfaction and repeat patronage intentions by varying factors such as servicescapes.

Another researcher defined that servicescapes are not only measurable, objectives and controllable stimuli but on contrary, they are also immeasurable, subjective, and often uncontrollable stimuli [36]. They also added to previous explored servicescapes; (physical and socialscapes) to new servicescapes natural and socially symbolicscapes. Physical environment is one of the servicescapes to reduce biasness due to wait perception which reduces the tendency of customer to overestimate the time passage during wait [37], by varying the physical environment of room. Therefore, biasness is a psychological disease having worse consequences and physical environment can be a clue to reduce it. Hence, service providers adjust their service setting so that they can avoid from negative word of mouth.

In addition, it was defined that physical environment as the controllable element in servicescapes and also said that it can be easily created with little effort to capture a big area and 
customer as well employees attitudes can be controlled [43]. Moreover, ambience factors include the impact of color on human personality. For example, a table sheet of white color and subdued lighting shows that restaurant is costly and full service restaurant. Similarly, dim lighting show a sense of affection and attachment with service, once affection is created with environment then customer will explore the environment and will stay more and ultimately his/her patronage behavior will increased [34].

Likely, if temperature is comfortable while waiting for service, then it also increases the spending pattern of individuals. If we check the impact of temperature on waiting customers then, it is worst if it will be below the normal temperature. As wait make the customer more annoyed, frustrated, and unhappy and if temperature were not comfortable then it would make them more annoyed, so marketing manager should adjust their temperature according to the environment. Similarly, music element also influence customer behavior and its effect vary from person to person but simple music has an influence on all type of customers $[33,40]$.

Design factors are visual part of servicescapes in nature that can be touched like room facilities, dining room layout, and color [4]. A number of studies are available that included design factors in their service setting to be part of physical environment so, providing facilities in service areas gained much more importance in academic and empirical literature [39]. Design factor increases customer emotions positively and ultimately it creates sense of coziness between customers [14].

H1: Physical environment of service setting has a positive influence on customer behavior during wait.

\subsection{Social Environment}

Social environment consists of employees displayed emotions and customer climate and according to theory of environmental psychology by social environment act as a Stimuli (S) that can have it affect on Organism (O) [28]. However, due to the era of competition, it has become increasingly difficult for service providers to differentiate its services from competitors so service environment can be used as fruitful opportunity for service differentiation. It would be a single time effort rather than improving quality of food repeatedly although, food quality has its own importance. Service firms must be sure that service environment should appeal to target customers. Therefore, service providers are investing their financial resources in making service environment so good that it can attract customers. Likewise, to understand experience and service encounter, role of emotions played a great role in social environment [25, 31, 35]. Customer emotions can only be made after providing a blend of service scapes such as physical environment and social environment. Once, service provider able to manage the customer emotions, then experience with service can be controlled.

H2: Social environment of service setting has a positive influence on customer behavior during wait.

\subsection{Employees Displayed Emotions}

Research was conducted to study emotional contagion showed that employee's gesture and facial expression during service could bring happiness on disgruntled and annoyed customer [38]. Because delays in service make customers unhappy, displeased, disgusted, so a healthy greeter form employees can bring a positive change on their face [22]. Actually, emotions are like a disease that spread from person to person, therefore employees little effort can also be the part of this change. Employees displayed emotions also matters when they are going to serve a nearby customer because every customer in service used to prefer and like other customer feeling and comments about service as they are from same group and class [22].

Frowning or smiling images has a great influence on annoyed and displeased customers and it can change the facial appearance of customers [27]. Likely, if portrait of smiling images are hanging on dining area wall then customer feel that are emotionally attach with that servicescapes. They will explore the environment, desired to stay their more, and feel that management have a deep concern of their time. However, if management makes able to realize the customer that this long haul wait is beyond their capacity then, it aftermath will be less and customer wants to stay there [29].

Customer climate is one of most important element in social environment. In past, the effect of other customer in service setting has been ignored and researches either on academic and empirical point of view has not been conducted because for firms, it can be difficult to approach and control strategically. To check the influence of social interaction among customers in service setting to making a good service experience, proposed that, service provider should be around the customers to ask then, interaction among customer is very important and it will ensure the continuity of service delivery [32].

For instance, customer density in dining area of restaurant and its effect on other customer depends on customer psyche as well as type of restaurant. Likewise, if it is a bar type restaurant, then people can wait even for hours because in bars their hedonic needs are being fulfilled. On the other hand, in normal restaurant people do irritate from wait and become annoyed, angry and disgusted. Conversely, customer evaluation of service during customers crowding and density also depends upon personality of individuals. Type A personality people can wait because they are more extroverted and can find opportunity for attraction with other customers. On other hand, the customer having type B personality are introverted, shyness, and less talkative and they are finding some lonely place. The negative effect of wait is more on type B people as compared to type A [19].

Interaction between customers during service setting also affects emotions of peoples that are consuming service at that time $[17,26]$.For instance, customers used to share their bad and good experience with other customers and may feel a state of annoyance and happiness so that at this particular 
time if management able to provide memorable in the form of social setting then this environment become as a mnemonic for them. Customers come for a service with some expectation in mind and they think it should be met at all cost else he get disgusted. However, when his/her expectation is aligned with other customer's behavior and manner, then it would cause to emerge new positive emotions. Similarly, if children are running and making noise near dining area then it could become the cause of negative feeling for nearby customers. Customer desired to stay in restaurant also depend upon type of tasks, which they have in hand.

\subsection{Customer Behavior During Wait}

Customer behavior is very un-predictable behavior that is difficult to read and to explain. However, in marketing management literature, it is being said that it can be observed by gestures and facial expression which he/she show while consuming service. Every customer has some expectation in mind when he comes for service and thinks that it should be met at all costs. However, if organization remained unable to meet that expectation then they can be dissatisfied and in the same way satisfied customer will practice approach behavior and will explore the information, spend more money, prefer to stay more, suggest other to visit that place and customer patronage intention will increase [28]. On the other hand, the customer who is dissatisfied, will practice avoidance behavior and prefer to exit from that environment, spend his/her time somewhere else.

Delays in services are making a customer behavior either good or bad. The environmental effects of physical and social settings on customer behavior in firms adjust based on situations. Customer will predict and evaluate the service in response to stimuli of physical and social environment [2]. For example, customer thinking and evaluating a service depend upon his preconceived knowledge and situations. Therefore, if firm make his environment memorable, then he/she will evaluate the service positively. The studies of conceptual management stated that physical environment affect satisfaction and behavior in organizations [10].
H3: Customer behavior has a positive effect on customer satisfaction.

H4: Physical environment of service setting influences positively on customer satisfaction through the customer behavior.

H5: Social environment of service setting influences positively on customer satisfaction through the consumer behavior.

\subsection{Customer Satisfaction}

Wait is the difference between perceived delays and actual delays in service because customers always overestimate the time. Whenever, a customer come for a service he/she has some expectation in mind that how long he/she would be served and when service provider fulfills their expectation then, they evaluated the service in friendly environment. To manage the satisfaction of customers, management has to plan their operations in such a way that its service process should be in multi-stage as the shortest possible wait occurs before the first stage [11]. Similarly, operation management suggests that process of service delivery should be in layers as there would be more number of employees and wait perception by customer would be less.

Managers should concern more about the perceived delays in service because perception is stronger until and unless it is delivered. Similarly, as service delays perception increases, customer satisfaction have a tendency to decrease [18].Perceiving of something bad is enough for making an individual mind and even it is difficult to change mind once it is settled so, this negative perception of time delay inclined to decrease in customer satisfaction. Delays in service are therefore said as bad customer experience and should be managed for mnemonic of service. Cultural background and personal expectation of waiting individual contribute to satisfaction with respect to wait [17]. Similarly, other factors such as personal expectation, duration, perceived injustice, and affective reaction are also contributing to customer satisfaction with wait $[1,37]$.

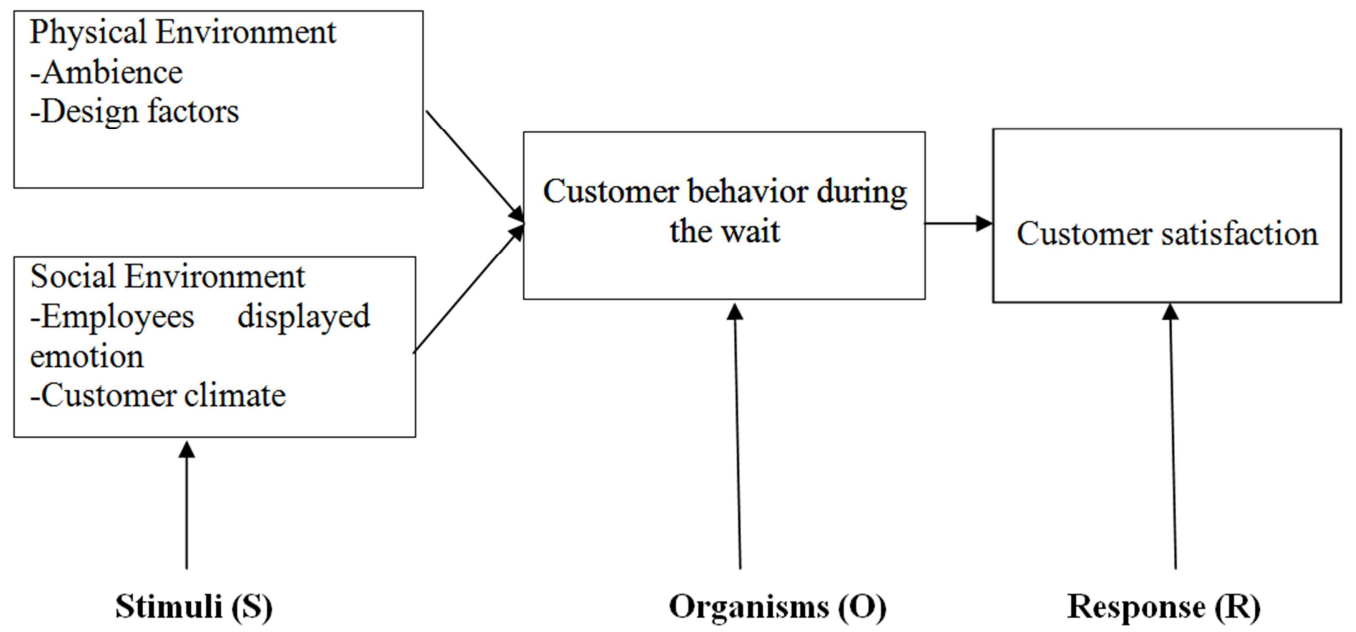

Figure 1. Framework of study. 


\section{Research Methodology}

Current study was exploratory in nature as it explored the relationship among variables with snowball sampling technique for its reason to bit difficult to find out the members of population due to people unknown behavior in visiting the restaurants. The sample size of this study was 375 and questioners were distributed to both male and female members visiting the restaurants however, the valid responses were 300. Likewise, questionnaires were adapted as ambience and design factors were measured through 5 items from scale of $[5,6,40]$. Employee displayed emotions were measured through 7 items from scale of [33, 38]. Customer climate was measured through 3 items from scale of [7]. Customer behavior during wait and distraction from wait are measured through 7 items from scale of [42] whereas, customer satisfaction is measured through 3 items from scale of [9].

\section{Results and Analysis}

In table 1, the analysis of demographic variables were explained in the shape of percentages, mean and standard deviation. There are 300 valid respondents which were analyzed on the demographic variables lie gender, marital status, age, qualification, and number of children with their mean and standard deviation value.

Table 1. Demographic characteristics.

\begin{tabular}{|c|c|c|c|c|c|}
\hline Demographic variables & Categories & Responses & Response rate (percent) & Mean & S.D. \\
\hline \multirow{2}{*}{ Gender } & Male & 189 & $63 \%$ & \multirow{2}{*}{.74} & \multirow{2}{*}{.438} \\
\hline & Female & 111 & $37 \%$ & & \\
\hline \multirow{2}{*}{ Marital status } & Single & 112 & $37.3 \%$ & \multirow{2}{*}{1.9} & \multirow{2}{*}{0.918} \\
\hline & Married & 188 & $62.7 \%$ & & \\
\hline \multirow{3}{*}{ Qualification } & HSS certificate & 22 & $7.3 \%$ & \multirow{3}{*}{2.535} & \multirow{3}{*}{1.170} \\
\hline & Bachelor and Hon's & 131 & $43.7 \%$ & & \\
\hline & Master and above & 138 & $46.0 \%$ & & \\
\hline \multirow{3}{*}{ Age } & Less than 20 & 6 & $2 \%$ & \multirow{3}{*}{1.57} & \multirow{3}{*}{.548} \\
\hline & 21-30 Years & 161 & $53.7 \%$ & & \\
\hline & Above 30 Years & 133 & $44.3 \%$ & & \\
\hline \multirow{5}{*}{ No of children } & No child & 137 & $45.7 \%$ & \multirow{6}{*}{1.75} & \multirow{6}{*}{.883} \\
\hline & One child & 35 & $11.7 \%$ & & \\
\hline & Two child & 50 & $16.7 \%$ & & \\
\hline & Three child & 43 & $14.3 \%$ & & \\
\hline & Five child & 1 & $0.3 \%$ & & \\
\hline Total & 300 & & & & \\
\hline
\end{tabular}

Table 2. Regression model summary.

\begin{tabular}{llll}
\hline Model & R square & Adjusted R square & Significance Value \\
\hline Model Summary & 0.257 & 0.262 & 0.000 \\
\hline
\end{tabular}

Independent Variable: Physical environment, Social environment

Dependent variable: Customer satisfaction

Table 3. Statistical parameters of hypotheses.

\begin{tabular}{|c|c|c|c|}
\hline Model & $\begin{array}{l}\text { Significance } \\
\text { value }\end{array}$ & $\begin{array}{l}\text { Std Coefficient } \\
\text { (Beta) }\end{array}$ & T-value \\
\hline Physical Environment & 0.001 & 0.193 & 3.283 \\
\hline Social Environment & 0.000 & 0.383 & 6.516 \\
\hline Customer Behavior & 0.463 & 0.463 & 9.015 \\
\hline
\end{tabular}

Independent Variable: Physical environment, Social environment, Customer behavior

Dependent Variable: Customer satisfaction

Table 2 depicted that when linear regression is being run, it gives the significance value of 0.000 that explains that over all model is significant. Likewise, the relationship between dependent and independent variable is also be accessed through other statistical values from regression table such as beta, t-value, and variance (R-squared). Total variance of model is being explained by $\mathrm{R}$ square of model and the value of $\mathrm{R}$ square show that our two independent variables are explaining the only $27 \%$ the relationship with dependent variables while rest $73 \%$ part of relationship is unexplained and it can be due to other factors.

In table 3, some statistical parameters were drawn from general linear model like, $t$-value, beta value of standardized and un-standardized coefficients. T-value should be above than 2 for acceptance of test and in current study t-value are greater than 2, so hypothesis is accepted. Similarly, the value of beta shows that one unit change in independent variable can change how many units in dependent variable so in this study, one unit change in physical environment will change $19 \%$ change in customer satisfaction and one unit change in social environment will change $38 \%$ change in customer satisfaction. All these parameters explain the significance level of model. Similarly, regression was being run one by one on all variables then significance value of physical environment variable with customer satisfaction is 0.001 . The rule of statistics shows that significance value should be less than 0.05 for the acceptance of relationship. Therefore, and this is acceptable according to statistical parameters. Similarly, the significance value of social environment with customer satisfaction is 0.000 that is also less than 0.05 and therefore acceptable for statistical parameters. Therefore, it is clear that independent variables (Predictor variable) have a relationship with dependent variable (customer satisfaction). 


\subsection{Testing of Mediating Variable Through AMOS}

In current study, the effect of mediating variable was checked through AMOS. Hence, data revealed that customer behavior is mediating the relationship between physical environment and customer satisfaction while on other hand; customer behavior is not mediating the relationship between social environment and customer satisfaction. In current study, there are two model fit summary that is output of AMOS, one is effect of mediating variable with physical environment on customer satisfaction and second model fit summary of mediating variable with social environment on customer satisfaction.

Following is the first model fit summary in which there is a good fit of data with Chi-square $(\chi 2)=138.6$, d.f. $=110$, $\mathrm{P}=0.025(\mathrm{p}<.05)$. Thomson et al, (2005) stated that if the value is less than 5 , then it would be satisfactory and acceptable and hence in this model, the value of $\chi 2 /$ d.f. is less than 5 so it is acceptable. There are also other indices like Incremental Fit Index (IFI), Goodness of Fit Index (GFI), Comparative Fit Index (CFI), Tucker-Lewis Index (TFI), Normed Fit Index (NFI), and Root Mean Square Error of Approximation (RMSEA) instead of $\chi^{2}$ and $\chi^{2} /$ d.f that are also used to check the fitness of model. However, in addition typical cut-off criteria of model fit can also be used to see the fitness indices. According to typical cut-off criteria, values of IFI, GFI, CFI, TFI and NMI should be equal or greater than 0.90 and the value of RMSEA should be less than 0.08. In diagram 4.1, there is output of AMOS in which the direct relationship between physical environment and customer satisfaction is 0.20 and when this relationship is controlled by customer behavior during wait, its value increased from 0.20 to 0.35 , so it is acceptable.

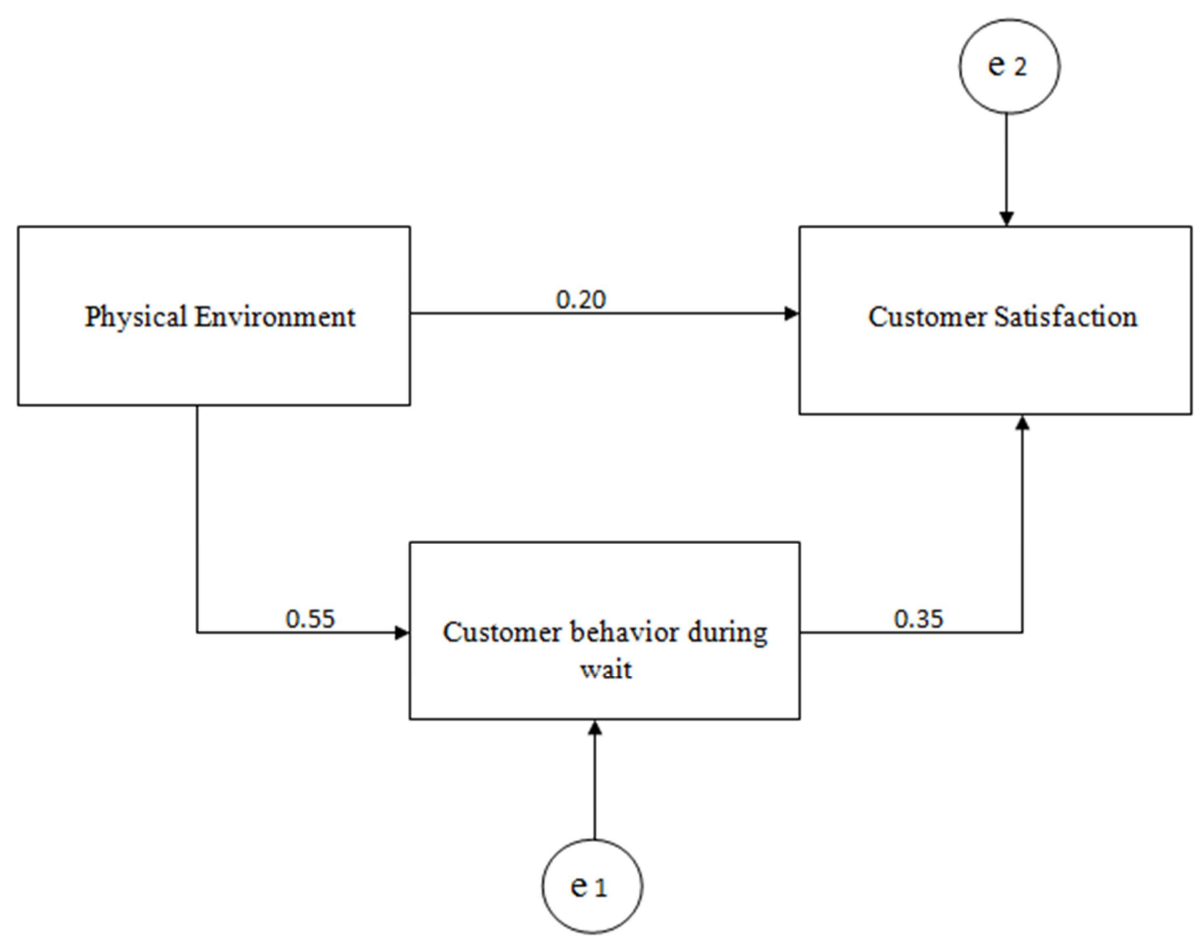

Figure 2. Effect of mediating behavior between relationship of physical environment and customer satisfaction through AMOS.

Table 4 shows the model summary of AMOS on the basis of which we can decide that theoretical model fit to data.

Table 4. Results of mediating variable on physical environment and customer satisfaction.

\begin{tabular}{lll}
\hline & Range & Results \\
\hline$\chi^{2} /$ d.f. & $<5$ & 1.26 \\
GFI & $\geq 0.90$ & 0.952 \\
IFI & $\geq 0.90$ & 0.979 \\
CFI & $\geq 0.90$ & 0.972 \\
NFI & $\geq 0.90$ & 0.990 \\
TLI & $\geq 0.90$ & 0.974 \\
RMSEA & $<0.08$ & 0.032 \\
\hline
\end{tabular}

In the current study, the values of $\chi 2=138.6$, d.f. $=110, \chi 2 /$ d.f. $=1.26, \mathrm{GFI}=952, \mathrm{IFI}=0.979, \mathrm{CFI}=0.972 \mathrm{NFI}=0.990$, $\mathrm{TLI}=0.974$ and RMSEA $=0.032$. All above indices supported that model is fit to accept the affect of mediating variable. 


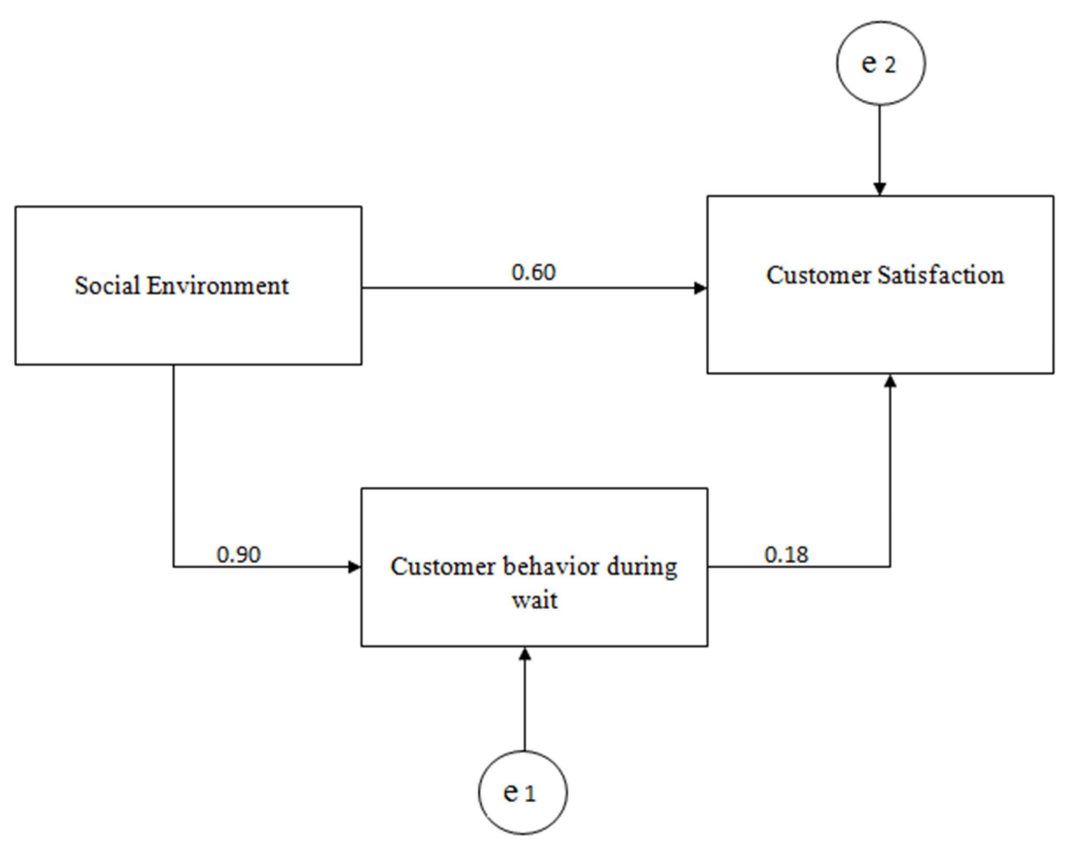

Figure 3. Effect of mediating behavior between relationship of social environment and customer satisfaction through AMOS

In figure3, there is output of AMOS in which the direct relationship between social environment and customer satisfaction is 0.60 and when this relationship is controlled by customer behavior during wait, its value decreased from 0.60 to 0.18 , so it is not acceptable.

Table 5. Results of mediating variable on social environment and customer satisfaction.

\begin{tabular}{lll}
\hline & Range & Results \\
\hline$\chi 2 /$ d.f. & $<5$ & 6.290 \\
GFI & $\geq 0.90$ & 0.810 \\
IFI & $\geq 0.90$ & 0.763 \\
CFI & $\geq 0.90$ & 0.647 \\
NFI & $\geq 0.90$ & 0.452 \\
TLI & $\geq 0.90$ & 0.554 \\
RMSEA & $<0.08$ & 0.101 \\
\hline
\end{tabular}

Statistical values that are drawn from this model fit is given as $\chi 2=691.9$, d.f. $=110, \chi 2 /$ d.f. $=6.290$, GFI $=.810$, IFI $=0.763$, $\mathrm{CFI}=0.647, \mathrm{NFI}=0.452$, TLI $=0.554$ and $\mathrm{RMSEA}=0.101$. These indices depicted badness of fit so, the customer behavior is not mediating the impact of social environment on customer satisfaction.

\subsection{Correlation}

Table 6. Pearson Correlation

\begin{tabular}{lllll}
\hline & Physical Environment & Social Environment & Customer behavior during wait & Customer satisfaction \\
\hline Physical environment & 1 & $0.530 * *$ & $0.161^{* *}$ & $0.396^{* *}$ \\
Sig Value (2-tailed) & 0.000 & 0.000 & 0.005 & 0.000 \\
N & 300 & 300 & 300 & 300 \\
Social environment & $0.530^{* *}$ & 1 & 0.010 & 0.485 \\
Sig Value (2-tailed) & 0.000 & 0.000 & 0.857 & 0.000 \\
N & 300 & 300 & 300 & 300 \\
Customer behavior & $0.161^{* *}$ & 0.010 & 1 & $0.146^{*}$ \\
Sig Value (2-tailed) & 0.000 & 0.857 & 0.000 & 0.012 \\
N & 300 & 300 & 300 & 300 \\
Customer satisfaction & $0.396^{* *}$ & $0.485^{* *}$ & $0.146^{*}$ & 1 \\
Sig Value (2-tailed) & 0.000 & 0.000 & 0.012 & 0.000 \\
N & 300 & 300 & 300 \\
\hline
\end{tabular}

**Correlation at 0.01 levels (2- tailed)

*Correlation at 0.05 levels (1-tailed)

Independent variable: Physical environment, Social environment

Dependent Variable: Customer satisfaction

Mediating Variable: Customer behavior during wait 
In the above table 6, the Pearson Coefficient of Correlation is given. The coefficient value of Independent variables physical environment with social environment is 0.530 and as per rule of thumb, this relation is strong and positive. Similarly, physical environment and customer behavior had a correlation coefficient value 0.161 that is medium correlation. Likewise, physical environment and customer satisfaction had correlation coefficient value of 0.396 that is medium and positive correlation. Moreover, Pearson correlation of social environment with customer behavior is 0.010 and its sig value is 0.857 and it shows that social environment have no significant relationship with customer behavior during wait. The correlation value of social environment with customer satisfaction is 0.485 and it have medium and positively correlated. Similarly, correlation value of customer behavior during wait and customer satisfaction is 0.146 that is positive correlated.

\section{Discussions}

In this globalized and competitive era, organizations always have a concern that services to customers should be provided to as earliest as possible and with all of convenience. In today's competitive era, there are more options and choices available to customers and they can easily switch to other service settings if an organization unable to manage. Therefore, in general to save the customer time and providing them more convenience, organizations use to apply many gimmicks. In services sector where there is direct interaction of customer with employees, this notion gets more importance. Current study was conducted to see the delays in service and its aftermath on customer behavior. Usually, in any case, people believe more on perception than reality and this thing has become a challenge for organizations to manage and manipulate their perception. Plethora of researches are available that customer always overestimate their waiting time in different scapes such as retail environment, banking industry, and shopping time and many researchers proved that this overestimation of waiting time is 40 to $50 \%$ as highlighted in literature.

Perception management is normally done by managing different scapes like physical and social dimension, natural dimension, and socially symbolic dimension. However, in current study two dimensions are included such as physical dimension and social dimension. Furthermore, in physical dimension, ambiance and design factors are included and their affect is checked on customer behavior during wait and ultimately its consequences on customer satisfaction. Similarly, in social dimension employees displayed emotion and customer climate are included and its affect is checked on customer behavior and its consequence on customer satisfaction. In current study, physical and social environment are independent variable, customer behavior during wait is mediating variable, and customer satisfaction is dependent variable. Likewise, five hypotheses were made to check the relationship between variable and among five, three were supported by data and rest two were not supported. Current study showed that physical environment always played a positive role in customer satisfaction and when customer controls this relationship behavior, its affect increased positively. Likewise, social environment did not play a positive role in customer satisfaction and when this effect is checked through mediating variable, it shows no impact on customer satisfaction. Therefore, it means that customer behavior during wait has to be controlled by the organization by providing different environment that can provide interaction between customers and environment.

\section{Conclusion}

The current study has new managerial implications that can be applied. From the perspective of customer's, service managers should manage such type of servicescapes that is socially supportive, physical appealing, naturally pleasing, and symbolically welcoming. Yet we all know customer perception change from time to time and all these servicescapes may not be important for them, that is what found in past researches that customers choices and stimuli change from time to time. This study also encourages other field researches like healthcare, hospitality industry, and natural psychology for extension in its implication and exploration of its potential in commercial perspective.

\section{References}

[1] Antonides, G., Verhoef, P. C., \& van Aalst, M. (2002). "Consumer perception and evaluation of waiting time: a field experiment". Journal of Consumer Psychology, 12 (3), 193202.

[2] Aubert-Gamet, V. (1997). "Twisting servicescapes: diversion of the physical environment in a re-appropriation process". International Journal in Service Industry Management, 8 (1), 26-41.

[3] Baker, J. (1986). "The role of the environment in marketing services: the consumer perspective" in Cecil, J.A et al. (Eds), The Services Challenge: Integrating for Competitive Advantage. Chicago, IL: American Marketing Association.

[4] Baker, J., Grewal, D., \& Parasuraman, A. (1994). "The influence of store environment on quality inferences and store image". Journal of the Academy of Marketing Science, 22 (4), 328-39.

[5] Baker, J., Parasuraman, A., Grewal, D., \& Vos. (2002). "The influence of multiple store environment cues on perceived merchandise value and patronage intentions". Journal of Marketing, 66 (2), 120-41.

[6] Bitner, M. J. (1992). "Servicescapes: The impact of physical surroundings on Customers and Employees". Journal of Marketing, 56, 57-71.

[7] Brady, M. k., \& Cronin, J. J. (2001). "Some new thoughts on conceptualizing perceived service quality: a hierarchical approach". Journal of Marketing, 65 (3), 34-49. 
[8] Chase, R. B., \& Dasu, S. (2001). "Want to perfect your company's service? Use behavioral science". Harvard Business Review, 76 (6), pp. 78-84.

[9] Chiou, J. S., Droge, C., \& Hanvanich, S. (2002). "Does customer knowledge affect how loyalty is formed?". Journal of Service Research, 5 (2), 113-24.

[10] Dale, K., \& Burrell, G. (2008). 4The Spaces of Organization \& The Organization of Space - Power, Identity \& Materiality at Work. Basingstoke: Palgrave Macmillan.

[11] Davis, M. M., \& Maggard, M. J. (1990). "How disconfirmation, perception, and actual waiting time in a twostage service process". Journal of Operation Management, 9 (3), 324-34.

[12] Geist, W. (1984, June 6). They are Hiring Others Stand in Line.

[13] Grewal, D., Baker, J., Levy, M., \& Voss, G. B. (2003). "The effects of waits expectations and store atmosphere evaluatios on patronage intentionsin service-intensive retail stores". Journal of Retailing, 79 (4), 259-68.

[14] Harris, L. C., \& Ezeh, C. (2008). "Servicescape and loyalty intentions: an empirical investigation". European Journal of Marketing, 42 (3/4), 390-422.

[15] Heung, V. S., Tsang, N., \& Cheng, M. (2009). Queuing behavior in theme parks: a comparison between Chinese and Western tourists". Journal of China Tourism Research, 5 (1), 1-51.

[16] Hornik, J. (1984). Subjective vs. Objective time measures:a note on the perception of time in consumer behavior. Journal of Consumer Research, 11 (1), 615-618.

[17] Huang, W. H. (2008). "The impact of other-customer failure on service satisfaction". International Journal of Service Industry Management, 19 (4), 521-36.

[18] Katz, Karen, Blaire, Larson, \& Richard, L. (1991). Perscription for the Waiting in Lines Blues: Entertain, Enlighten, and Engage. Sloan Management Review (Winter), 44-53.

[19] Kim, N., \& Lee, M. (2012). "Other customers in a service encounter:examining the effect in a restaurant setting". Journal of Services Marketing, 26 (1), 27-40.

[20] Koseluk, C. (2004). Are we there yet? (Vol. 116). Amusement Business.

[21] Kotler, P. (1973). "Atmospherics as a marketing tool”. Journal of Retailing, 49 (4), 48-64.

[22] Lin, J.-S. C., \& Liang, H.-L. (2011). "The influence of Service Environments on Custoemr emotions and customers outcomes". Management Service Quality, 21 (Nov), 350-372.

[23] Maister, D. (1985). The Psychology of Wating Lines," in th eService Encounter (John Czepeil, Michael Solomon, and Carol Suprenant, ed ed.). Lexington: Lexington Books.

[24] Martin, C. L. (1996). "Consumer-to-consumer relationships: satisfaction with other consumers' public behavior". Journal of Consumer Affairs, 30 (1), 146-69.

[25] Mattila, A. S., \& Enz, C. A. (2002). "The role of emotions in service encounters". Journal of Service Research, 4 (4), 268-77.

[26] McGrath, M. A., \& Otnes, C. (1995). "Unacquainted Influencers: When stranger interact in the Retail Setting".
Journal of Business Research, 32, 261-272.

[27] McHugo, G. J., Sullivan, D. G., Lanzetta, J. T., Masters, R. D., \& Englis, B. G. (1985). "Emotional reactions to the expressive displays of a political leader". Journal of Personality and Social Psychology, 3 (3), 1513-29.

[28] Mehrabian, A., \& Russell. (1974). An approach to Environmental Psychology. Cambridge, MA: MIT Press.

[29] Mobach, M. P. (2013). "The impact of physical changes on customer behavior". Management Research Review, 36 (3), 278-295.

[30] Oakes, S., \& North, A. C. (2008). "Reviewing congruity effects in the service environment musicscape". International Journal of Service Industry Management, 19 (1), 63-82.

[31] Oliver, R. L. (1997). Satisfaction: A Behavioral Perspective on the Consumer. NY: McGraw-Hill, New York.

[32] Parker, C., \& Ward, P. (2000). "An analysis of role adoptions and scripts during customer-to-customers encounters". European Journal of Marketing, 34 (3/4), 341-358.

[33] Pugh, S. D. (2001). "Service with a smile: emotional contagion in the service encounter". Academy of of Management Journal, 44 (5), 1018-27.

[34] Reil, A. C., Semeijn, J., Ribbink, D., \& Bombert-Peters, Y. (2012). "Waiting for service at the checkout:Negative emotional responses, store image, and overall satisfaction". Journal of Service Management, 23 (2), 144-169.

[35] Richins, M. L. (1997). "Measuring emotions in the consumption experience". Journal of Consumer Research, 24 (2), 127-46.

[36] Rosenbaum, M. S., \& Massiah, C. (2011). "An expanded servicescape perspective". Journal of Service Management, 22 (4), 471-490.

[37] Seawright, K. K., \& Sampson, S. E. (2007). A video method for empirically studying wait perception bias. Journal of Operation Management, 25 (5), 1055-66.

[38] Tsai, W. C., \& Huang, Y. M. (2002). "Mechanisms linking employee affective delivery and customer behavioral intentions". Journal of Applied Psychology, 87 (5), 1001-8.

[39] Turley, L. W., \& Milliman, E. R. (2000). "Atmospheric effects on Shopping Behavior:A reviw of Experimantal Evidence". Journal of Business Research, 49, 193-211.

[40] Whiting, A., \& Donthu, N. (2009). "Closing the gap between perceived and actual waiting times in a call center:results from a field study". Journal of Services Marketing, 23 (5), 279-288.

[41] Yoo, C., Park, J., \& MacInnis, D. J. (1998). "Effects of store characteristics and in-store emotional experiences on store attitude". Journal of Business Research, 42 (3), 253-63.

[42] Zakay, D., \& Hornik, J. (1991). How much time did you wait in line? A time perception perspective('Chebat,J.C.andVenkatesan,V. ed.).UQAM,MontreÂal,Canada: Proceedings of the VIIth John-Labatt Marketing Reseach Seminar, Time and Consumer Behavior.

[43] Zeithmal, V. A., Bitner, M. J., \& Gremler, D. D. (2009). Service marketing:Integrating Customer Focus across the Firm."Boston, MA: McGraw-Hill/Irwin. 